\title{
EFFECT OF A NOVEL THIAZOLE DERIVATIVE AND ITS COMPLEX WITH A POLYMERIC CARRIER ON STABILITY OF DNA IN HUMAN BREAST CANCER CELLS
}

\author{
N. S. FINIUK ${ }^{1,2}$, O. YU. KLYUCHIVSKA ${ }^{1}$, I. I. IVASECHKO ${ }^{1}$, \\ N. E. MITINA ${ }^{3}, Y$ Y . V. OSTAPIUK ${ }^{2}$, M. D. OBUSHAK ${ }^{2}$, \\ O. S. ZAICHENKO ${ }^{3}$, A. M. BABSKY ${ }^{2}$, R. S. STOIKA ${ }^{1,2 \square}$ \\ ${ }^{1}$ Institute of Cell Biology, NAS of Ukraine, Lviv, Ukraine; \\ ${ }^{2}$ Ivan Franko National University of Lviv, Lviv, Ukraine; \\ ${ }^{3}$ Lviv Polytechnic National University, Lviv, Ukraine; \\ 凶e-mail: stoika.rostyslav@gmail.com
}

Received: 26 January 2021; Accepted: 2021

Thiazole derivatives are perspective antitumor compounds characterized by a broad range of bioactivity, while polymeric carriers are widely used to enhance the efficiency of biological action of drugs, improve their biocompatibility and water solubility. Previously, we identified that the thiazole-based derivative BF1 (N-(5-benzyl-1,3-thiazol-2-yl)-3,5-dimethyl-1-benzofuran-2-carboxamide) possessed differential toxicity towards targeted tumor cell lines. The aim of the present work was to investigate the action in vitro of BF1 and its complex with the polymeric carrier (PC) poly(PEGMA-co-DMM) (BF1-PC complex) towards human breast adenocarcinoma cells of the MDA-MB-231 and MCF-7 lines. DNA comet analysis, diphenylamine DNA fragmentation assay, gel retardation assay of plasmid DNA, DNA intercalation assay using methyl green dye and fluorescent microscopy were used to study the effects of BF1 on DNA stability in breast cancer cells. The $I C_{50}$ of cytotoxic action towards $M D A-M B-231$ cells was $26.5 \pm 2.9 \mu M$ for BF1, while the $I C_{50}$ for the BF1$P C$ complex was $6.9 \pm 0.4 \mu \mathrm{M}$, and the PC demonstrated low toxicity $\left(I_{50}>50 \mu \mathrm{M}\right)$. The BF1-PC complex possessed higher toxicity towards $M C F-7$ cells than free BF1, with $I C_{50}$ of $9.6 \pm 0.8 \mu M$ and $15.8 \pm 0.9 \mu M$, respectively. BF1 and BF1-PC induced an increase in the number of damaged cells of the MDA-MB-231 line with blebbing of plasma membrane, condensed chromatin and/or fragmented nucleus and micronuclei formation. Both BF1 and the BF1-PC complex induced single-strand breaks in DNA and its fragmentation in treated MDA-MB-231 cells. The studied compounds were not bound to plasmid DNA and did not intercalate into DNA molecules.

Ke ywords: thiazole derivative, polymeric carrier, cytotoxic action, breast cancer cells, DNA damage, DNA comet analysis, DNA intercalation.

\section{Introduction}

Cancer is a serious global health problem that is characterized by abnormal and uncontrolled cell division [1, 2]. Breast cancer is the second most frequent cause of death among women [1, 3]. Chemotherapy (hormonal or nonhormonal), radiotherapy and surgery are used for breast cancer treatment. However, the resistance of breast cancer cells to chemotherapy is rapidly developing [1, 4]. Thus, it is crucial to develop novel treatment strategies.
The thiazole derivatives are characterized by a wide range of biological activities (anticancer, antibacterial, antifungal, antiviral, anti-inflammatory, neuroprotective) [1, 5-11]. Anticancer activity was reported for tiazofurin, dasatinib, and a furan-thiazole hybrid [11, 12].

Currently, nanomaterials are one of the most promising systems for clinical application, such as drug carriers, gene delivery and imaging agents [13-15]. Liposomes, polymeric micelles, dendrimers,

(C) 2021 Finiuk N. S. et al. This is an open-access article distributed under the terms of the Creative Commons Attribution License, which permits unrestricted use, distribution, and reproduction in any medium, provided the original author and source are credited. 
quantum dots, biodegradable polymeric materials, and hybrid inorganic/organic nanomaterials are of great clinical and commercial interest $[16,17]$. The polymeric carriers are water-soluble, biocompatible, stable during long periods of storage, and can be easily modified $[14,18]$. They are currently being tested in several preclinical and clinical trials $[14,19]$.

In previous studies, we have shown that the thiazole derivative $\mathrm{N}$-(5-benzyl-1,3-thiazole2-yl)-3,5-dimethyl-1-benzofuran-2-carboxamide (BF1) inhibited growth of cancer cells of different tissue origins (e.g. glioma, melanoma and leukemia cells) [20, 21]. It was reported that BF1 conjugated with polymeric carriers (PCs) based on poly(VEPco-GMA)-graftmPEG, poly(PEGMA), and poly(PEGMA-co-DMM) enhanced the cytotoxic action of BF1 towards tumor cells in vitro. Complexes of BF1 with poly(PEGMA-co-DMM) demonstrated higher growth inhibition activity for HepG2 human hepatocarcinoma cells, C6 rat glioma cells and HL60 human promyelocytic leukemia cells, compared with the effects of the free form of BF1 [22].

In the present study, we further investigated the action of thiazole derivative BF1 in complex with the PC poly(PEGMA-co-DMM) compared to free BF1 and free poly(PEGMA-co-DMM) towards proliferation and DNA damage in breast cancer cells.

\section{Materials and Methods}

Thiazole derivative and its complexation with the PC. The thiazole derivative N-(5-benzyl1,3-thiazole-2-yl)-3,5-dimethyl-1-benzofuran-2carboxamide (BF1, Fig. 1) was synthesized at the
Department of Organic Chemistry of Ivan Franko National University of Lviv (Ukraine) as described earlier [20, 21]. The initial $10 \mathrm{mM}$ solution of BF1 was prepared in dimethyl sulfoxide (DMSO, SigmaAldrich, St. Louis, Missouri, USA). Working solutions were prepared by a dilution in a cell culture medium.

The PC poly(PEGMA-co-DMM) (Fig. 1) was synthesized at the Department of Organic Chemistry of Lviv Polytechnic National University (Ukraine). The PC was synthesized in dioxane by the method of radical(co)polymerization of PEG-containing macromere after the initiation of azobis(isobutyronitrile) in the presence of isopropyl benzene as the polymer chain length regulator [23].

The PC and BF1 were dissolved in DMSO, and the solutions were subsequently transferred to water, forming the BF1-PC complexes. Initially, $45 \mathrm{mg}$ of PC were dissolved in $0.15 \mathrm{ml}$ of DMSO and $1.5 \mathrm{~g}$ of BF1 were dissolved in $0.1 \mathrm{ml}$ of DMSO. The PC and BF1 solutions were mixed, added to $4.25 \mathrm{ml}$ of $0.9 \%$ $\mathrm{NaCl}$ water solution (physiological solution), and subjected to ultrasound (US) dispersion for $10 \mathrm{~s}$. The free PC solution was prepared by dilution of $45 \mathrm{mg}$ of PC in $0.45 \mathrm{ml}$ of DMSO. Then, it was added to $4.0 \mathrm{ml}$ of physiological solution and subjected to US dispersion for $10 \mathrm{~s}$ [24].

Cell culture. Human breast adenocarcinoma cells of the MDA-MB-231 and MCF-7 lines were kindly provided by a Collection at the Institute of Molecular Biology and Genetics, National Academy of Sciences of Ukraine (Kyiv, Ukraine) that had received those cells from the American Type Culture Collection (ATCC). Cells were cultivated in Dul-
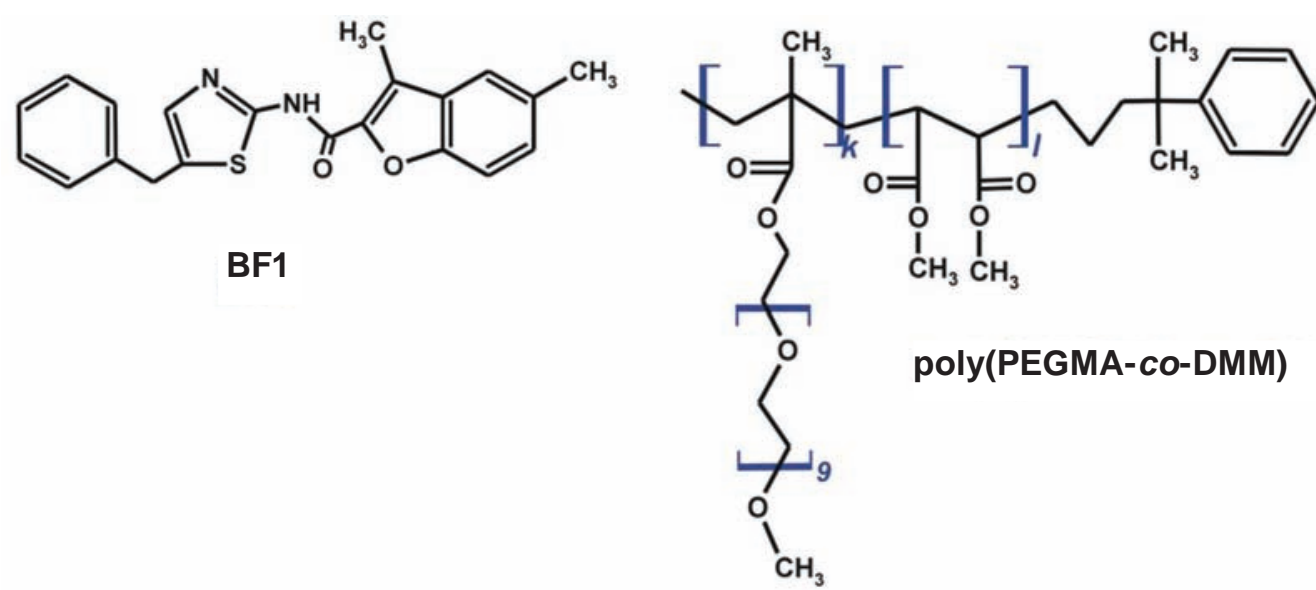

Fig. 1. Structure of thiazole derivative BF1 and polymeric carrier $(P C)$ poly (PEGMA-co-DMM) $(k=87 \%$ $\mathrm{mol}, \mathrm{l}=13 \% \mathrm{~mol}, M_{n}=47 \mathrm{kDa}$ ) 
becco's modified Eagle's medium (DMEM) medium supplemented with $10 \%$ fetal bovine serum (both were purchased from Biowest, Nuaille, France) in a $\mathrm{CO}_{2}$ thermostat system at $37^{\circ} \mathrm{C}$ with atmosphere of 95\% air and 5\% $\mathrm{CO}_{2}$ [21].

MTT assay. The effects of free BF1, free PC, BF1-PC complex, and doxorubicin (Dox, Actavis, Bucharest, Romania) on proliferation of the MDAMB-231 and MCF-7 cell lines were examined using the MTT (3-(4,5-dimethyl thiazol-2-yl)-2,5-diphenyl tetrazolium bromide) test (Sigma-Aldrich, St. Louis, Missouri, USA). Cells were seeded overnight into 96-well plates in $100 \mu \mathrm{l}$ at concentrations of 5,000 cells/well. Aliquots of $100 \mu \mathrm{l}$ of experimental compounds $(0-50 \mu \mathrm{M})$ were added to the cell cultures. Cells were incubated for the next $72 \mathrm{~h}$. MTT was added to the cells. The reaction products were measured by an Absorbance Reader BioTek ELx800 (BioTek Instruments, Inc., Winooski, VT, USA). The $\mathrm{IC}_{50}$ of tested compounds was calculated as the drug concentration that caused $50 \%$ reduction in cell viability [25].

Gel retardation assay of plasmid DNA. Plasmid DNA $(1 \mu \mathrm{g} / \mu \mathrm{l})$ pEGFPc-1 (Clontech, Mountain View, California, USA) was mixed with $1 \mu 1$ of BF1 or BF1-PC, or PC (all at $10 \mu \mathrm{M})$, or Dox $(1 \mu \mathrm{M})$ in $18 \mu \mathrm{l}$ of $0.9 \% \mathrm{NaCl}$ water solution (physiological solution) (Arterium, Lviv, Ukraine) at room temperature for $1 \mathrm{~h}$. The prepared mixture was analyzed by electrophoresis in $1 \%$ agarose gel (Lachema, Brno, Czech Republic) with $1 \times$ Tris acetate buffer containing $1 \mu \mathrm{g} / \mathrm{ml}$ of ethidium bromide (EtBr, SigmaAldrich, St. Louis, Missouri, USA) for $30 \mathrm{~min}$ at a constant voltage of $90 \mathrm{~V}$. A trans-illuminator (MacroVue UV-20, Hoeffer Pharmacia Biotech Inc., San Francisco, California, USA) was used for visualization of plasmid DNA [21].

DNA intercalation assay using methyl green method. $485 \mu \mathrm{l}$ of salmon sperm DNA $(50 \mu \mathrm{g} / \mathrm{ml}$, Sigma-Aldrich, St. Louis, Missouri, USA) were incubated for $1 \mathrm{~h}$ at $37^{\circ} \mathrm{C}$ with $15 \mu \mathrm{l}$ of methyl green (Sigma-Aldrich, St. Louis, Missouri, USA) solution ( $1 \mathrm{mg} / \mathrm{ml}$ in $\mathrm{H}_{2} \mathrm{O}$ ). $500 \mu \mathrm{l}$ of the compounds BF1, or $\mathrm{BF1}$-PC, or PC, or Dox (all at $10 \mu \mathrm{M}$ ) were added to the methyl green-DNA complex and incubated for the next $2 \mathrm{~h}$ at $37^{\circ} \mathrm{C}$ in the dark. $\operatorname{EtBr}(10 \mu \mathrm{M})$ was used as a positive control. Absorption of methyl green was measured at $630 \mathrm{~nm}$ using a fluorescence plate reader (Absorbance Reader BioTek ELx800, BioTek Instruments, Inc., Winooski, Vermont, USA) $[25,26]$.
Diphenylamine assay of DNA fragmentation. The MDA-MB-231 cells were treated for $24 \mathrm{~h}$ with tested compounds at concentrations that corresponded to their IC $_{50}$ value: BF1 $(27 \mu \mathrm{M})$, BF1-PC $(7 \mu \mathrm{M})$, PC $(7 \mu \mathrm{M})$, Dox $(0.6 \mu \mathrm{M})$; and DMSO $(270 \mu \mathrm{g} / \mathrm{ml}$ corresponding to the solvent concentration of BF1 at $27 \mu \mathrm{M}$ ). Cells were lysed in $0.5 \mathrm{ml}$ of Tris-EDTA buffer, $\mathrm{pH} 7.4$, supplied with $0.2 \%$ Triton $\mathrm{X}-100$ and centrifuged for $10 \mathrm{~min}$ at $12,000 \mathrm{~g}$ at $4^{\circ} \mathrm{C}$. Supernatant that contained fragmented DNA (labelled as "B") was transferred into a new tube. The tube with a sediment which contained intact chromatin was labelled as "A". The $0.5 \mathrm{ml}$ of $25 \%$ trichloroacetic acid (Sfera Sim, Lviv, Ukraine) was added to tubes "A" and " $\mathrm{B}$ ", mixed and incubated for $1 \mathrm{~h}$ at $56^{\circ} \mathrm{C}$. The samples were centrifuged for $10 \mathrm{~min}$ at $14,000 \mathrm{~g}$ at $4^{\circ} \mathrm{C} .1 \mathrm{ml}$ of freshly prepared diphenylamine reagent (150 mg diphenylamine (Sigma Aldrich, St. Louis, Missouri, USA) diluted in $10 \mathrm{ml}$ of glacial acetic acid, $150 \mathrm{ml}$ of concentrated $\mathrm{H}_{2} \mathrm{SO}_{4}$, and $50 \mathrm{ml}$ of acetaldehyde solution) was added to pellets "A" and "B" and incubated overnight at $37^{\circ} \mathrm{C}$. The optical density (OD) of the colored solution was measured at $630 \mathrm{~nm}$ using Absorbance Reader BioTek ELx800 (BioTek Instruments, Inc., Winooski, Vermont, USA). The percentage of DNA fragmentation was calculated as \{OD tube $\mathrm{B} /(\mathrm{OD}$ tube $\mathrm{A}+\mathrm{OD}$ tube B) $\times 100 \%\}[25,27]$.

DNA comet assay in alkaline conditions. The MDA-MB-231 cells were treated for $24 \mathrm{~h}$ with compounds at concentrations that corresponded their $\mathrm{IC}_{50}$ value: BF1 (27 $\mu \mathrm{M})$, BF1-PC $(7 \mu \mathrm{M})$, PC $(7 \mu \mathrm{M})$, Dox $(0.6 \mu \mathrm{M})$; and DMSO $(270 \mu \mathrm{g} / \mathrm{ml}$ corresponding to the solvent concentration of BF1 at $27 \mu \mathrm{M}) .100 \mu \mathrm{l}$ of treated cells $(n=25,000)$ were mixed with $100 \mu \mathrm{l}$ of $0.5 \%$ low melting point agarose (Promega, Madison, Wisconsin, USA) and transferred to microscopic slides covered with $1 \%$ normal molten agarose (Lachema, Brno, Czech Republic). Cells were incubated for $4-6 \mathrm{~h}$ at $4^{\circ} \mathrm{C}$ in lysis buffer [21]. Electrophoresis was performed at $25 \mathrm{~V}$ for $25 \mathrm{~min}$ in a buffer $(1 \mathrm{mM}$ EDTA; $300 \mathrm{mM} \mathrm{NaOH}, \mathrm{pH} 13.0)$ at $4^{\circ} \mathrm{C}[21,28]$. Slides were stained with $\mathrm{EtBr}(10 \mu \mathrm{g} / \mathrm{ml}$, Sigma-Aldrich, St. Louis, Missouri, USA), and visualization was performed under a Zeiss fluorescent microscope with AxioImager A1 camera (Carl Zeiss, Birkerod, Germany) using AxioVision image analysis software Release 4.6.3.0 for Carl Zeiss microscopy (Imaging Associates Ltd., Cork, Ireland, UK). The Casplab1.2.3b2 software (CASPLab, Wroclaw, Poland) was used for calculation of the olive tail moment (OTM), and percentage of DNA in the tail of the comet [21]. 
Fluorescence microscopy of cells. The MDAMB-231 cells were seeded on glass microscopic slides in 12-well plates, and then treated for $24 \mathrm{~h}$ with BF1 (27 $\mu \mathrm{M})$, BF1-PC $(7 \mu \mathrm{M})$, PC $(7 \mu \mathrm{M})$, Dox $(0.6 \mu \mathrm{M})$, and DMSO $(270 \mu \mathrm{g} / \mathrm{ml}$ that corresponded to solvent concentration in BF1 solution at $27 \mu \mathrm{M}$ ). Cells were additionally incubated for 30 min with Hoechst-33342 (0.5 $\mu \mathrm{g} / \mathrm{ml}$, Sigma-Aldrich, St. Louis, Missouri, USA). Propidium iodide $(20 \mu \mathrm{g} / \mathrm{ml}$, Sigma-Aldrich, St. Louis, Missouri, USA) was added immediately before cell examination using a Zeiss fluorescent microscope (Carl Zeiss, Jena, Germany) and Axio Imager A1 camera (400× magnification) [21]. All photomicrographs were further analyzed using Image Pro 7 software (Media Cybernetics, Rockville, Maryland, USA).

Ethical Committee. This research did not involve human or animal investigations.

Statistical analysis. The results were analyzed and illustrated with GraphPad Prism 6 (GraphPad Software, La Jolla, California, USA), and presented as the mean \pm standard deviation of two repeats each with two parallels $(n=4)$. The ANOVA test (by Dunnett's test) was used for analysis of statistical data. The $P$-value of $<0.05$ was considered to be statistically significant.

\section{Results}

Dose-dependent cytotoxic effects. The antiproliferative effects in vitro of free BF1, its complex with the PC (BF1-PC), free PC, and Dox were investigated in human breast adenocarcinoma cell lines
MDA-MB-231 and MCF-7 after treatment for $72 \mathrm{~h}$. The treated cells were analyzed using MTT testing.

Similar dose-dependent inhibition of cell viability of both MDA-MB-231 and MCF-7 cells was found under the effects of BF1, BF1-PC, PC, and Dox. BF1 achieved its $\mathrm{IC}_{50}$ for MDA-MB-231 cells at the dose of $26.5 \mu \mathrm{M} \pm 2.9 \mu \mathrm{M}$, while the $\mathrm{IC}_{50}$ of BF1-PC was $6.9 \pm 0.4 \mu \mathrm{M}$ (Fig. 2). The $\mathrm{IC}_{50}$ of $\mathrm{BF} 1$ was $15.8 \pm 0.9 \mu \mathrm{M}$ for MCF-7 cells, while the $\mathrm{IC}_{50}$ of BF1-PC was $9.6 \pm 0.8 \mu \mathrm{M}$. The PC did not reach an $\mathrm{IC}_{50}$ value at concentrations up to $50 \mu \mathrm{M}$ (Fig. 2). It was observed that $83.2 \%$ of MDA-MB-231 cells and $77.2 \%$ of MCF-7 cells were alive after treatment with $\mathrm{PC}$ at $50 \mu \mathrm{M}$. The $\mathrm{IC}_{50}$ of Dox was $0.63 \pm 0.05 \mu \mathrm{M}$ for MDA-MB-231 cells, and $0.62 \pm 0.04 \mu \mathrm{M}$ for MCF-7 cells (Fig. 2).

Thus, the BF1-PC complex possessed higher activity in growth inhibition of MDA-MB-231 and MCF-7 cells. The cytotoxic action of BF1-PC was approximately 4 times higher $(P<0.001)$ compared to the action of free BF1 towards MDA-MB-231 cells, and approximately 1.6 times higher $(P<0.001)$ compared to the action of free BF1 towards MCF-7 cells.

DNA binding and intercalation. The interaction of anticancer drugs with DNA is one of the mechanisms of their action. Electrophoresis was used to examine the ability of BF1, BF1-PC complex, free PC, and Dox (used as a reference drug) to bind with DNA. Dox $(1 \mu \mathrm{M})$ inhibited the electrophoretic mobility of plasmid DNA pEGFPc-1 (Fig. 3, lane 2). The plasmid DNA pEGFPc-1 was not retarded by BF1, BF1-PC complex, or free PC (Fig. 3, lanes 3-5).
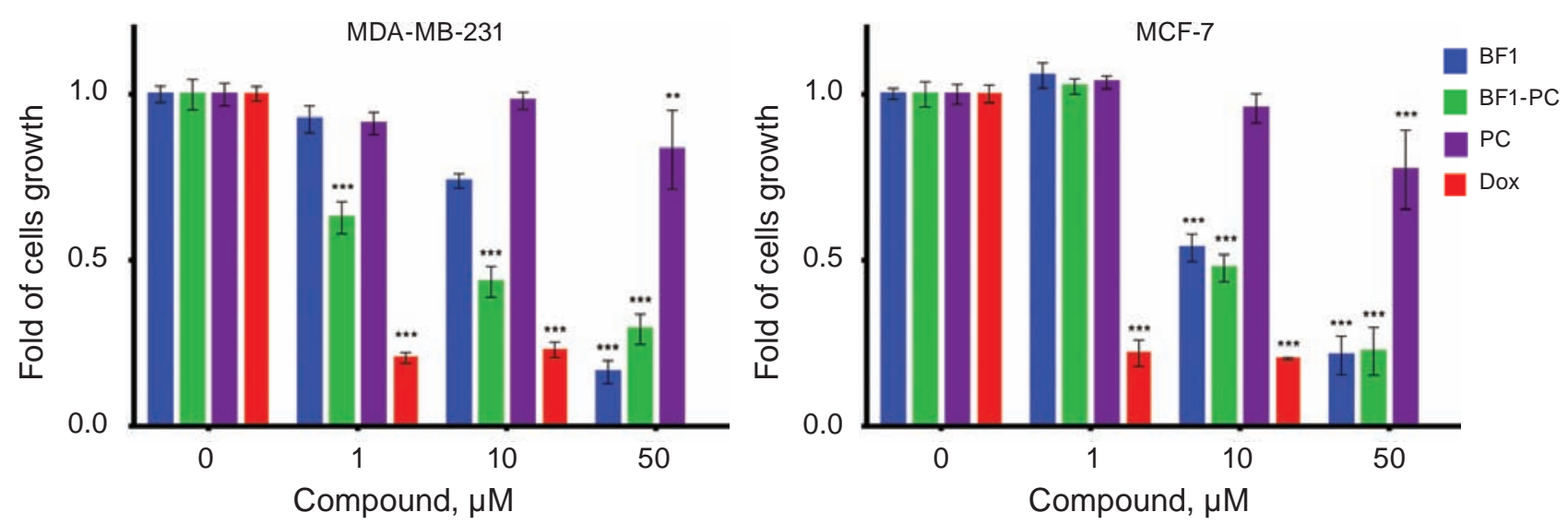

Fig. 2. Dose-dependent cytotoxic effects of the thiazole derivative BF1, its complex with the PC (BF1-PC), free $P C$, and Dox towards human breast adenocarcinoma cell lines MDA-MB-231 and MCF-7. Data are presented as mean $M \pm S D(n=4)$. ${ }^{* *} P<0.001$ (significant changes compared with BF1). Dox, doxorubicin; PC, polymeric carrier poly(PEGMA-co-DMM) 


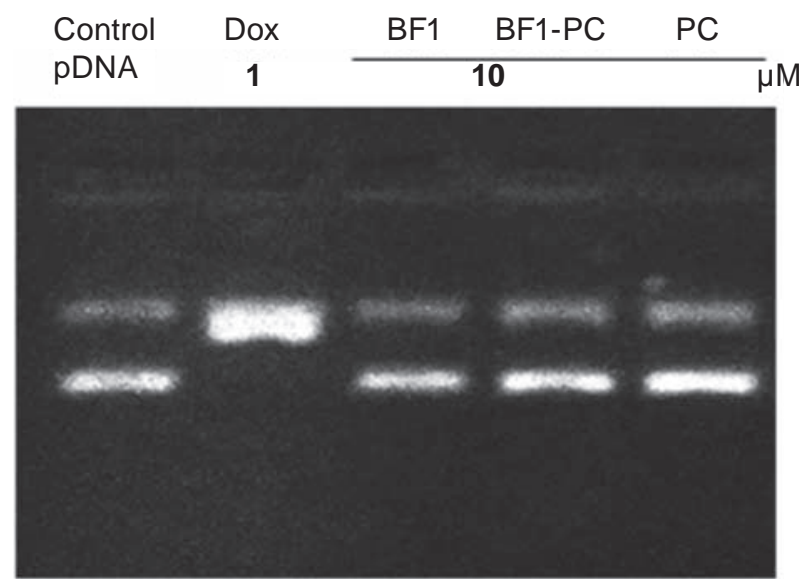

Fig. 3. The results of electrophoretic retardation of plasmid DNA ( $p D N A)$ pEGFPc-1 by doxorubicin (Dox, $1 \mu \mathrm{M})$, thiazole derivative BF1 (10 $\mu \mathrm{M})$, its complex with the PC (BF1-PC, $10 \mu \mathrm{M})$, and free PC $(10 \mu M)$. PC, polymeric carrier poly(PEGMA-co$D M M)$

Because compounds that intercalate into DNA replace methyl green dye from the DNA-methyl green complex [25, 26], the methyl green assay was conducted to examine the ability of BF1, BF1-PC complex, free PC, and Dox to intercalate into the DNA molecule. BF1 $(10 \mu \mathrm{M})$ replaced $2.1 \pm 0.4 \%$ and BF1-PC $(10 \mu \mathrm{M})$ replaced $3.2 \pm 0.5 \%$ of the

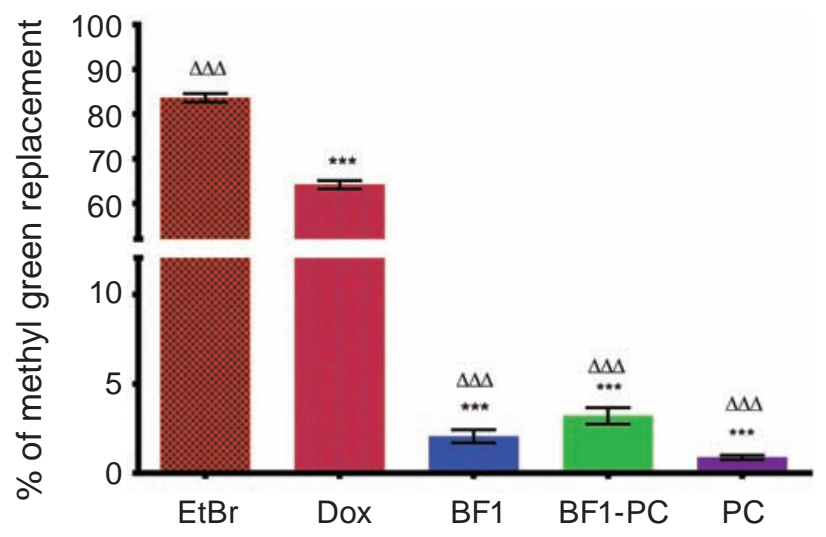

Fig. 4. The percentage of replaced methyl green dye from the DNA-methyl green complex by the thiazole derivative BF1 $(10 \mu \mathrm{M})$, its complex with the PC (BF1-PC, $10 \mu M)$, free PC $(10 \mu M)$, and the positive controls doxorubicin (Dox, $10 \mu \mathrm{M})$ and ethidium bromide (EtBr, $10 \mu \mathrm{M})$. $* * * P<0.001$ (significant changes compared with EtBr $(10 \mu M)$ effect); ${ }^{\triangle 4} P<0.001$ (significant changes compared with Dox $(10 \mu M)$ effect). Data are presented as mean $\pm S D$ $(n=4)$. PC, polymeric carrier poly(PEGMA-co$D M M)$ methyl green from the DNA-methyl green complex (Fig. 4). Free PC slightly replaced the methyl green $(0.9 \pm 0.1 \%)$. Dox $(10 \mu \mathrm{M})$ used as a positive control replaced $64.2 \pm 0.9 \%$ of the methyl green. The reference compound, $\mathrm{EtBr}(10 \mu \mathrm{M})$, demonstrated $83.6 \pm 1.0 \%$ of methyl green replacement. Thus, BF1, BF1-PC complex and free PC did not bind and intercalate with DNA.

Induction of DNA damage in breast cancer cells. Next, we evaluated the amount of DNA fragmentation in MDA-MB-231 cells after treatment with BF1, BF1-PC, PC, and Dox using a colorimetric diphenylamine (Barton's) assay. An increased content of fragmented DNA was observed in MDAMB-231 cells under the action of BF1, BF1-PC, and Dox (Fig. 5). Induced DNA fragmentation was $7.3 \pm 0.9 \%$ for BF1 $(27 \mu \mathrm{M}), 6.0 \pm 0.6 \%$ for BF1PC $(7 \mu \mathrm{M})$ and $17.7 \pm 0.7 \%$ for Dox $(0.6 \mu \mathrm{M})$. Some DNA fragmentation $(1.1 \pm 0.08 \%)$ was observed in MDA-MB-231 cells treated with PC. The solvent DMSO caused $0.7 \pm 0.08 \%$ of DNA fragmentation.

The DNA comet assay at alkaline $\mathrm{pH}$ was used to identify the potential of BF1, BF1-PC complex, free $\mathrm{PC}$ and Dox to induce single-strand DNA breaks and lesions in the treated MDA-MB-231 cells. BF1 $(27 \mu \mathrm{M})$ caused significant DNA damage, with the content of DNA in the comet's tail equal to $16.4 \%$

MDA-MB-231

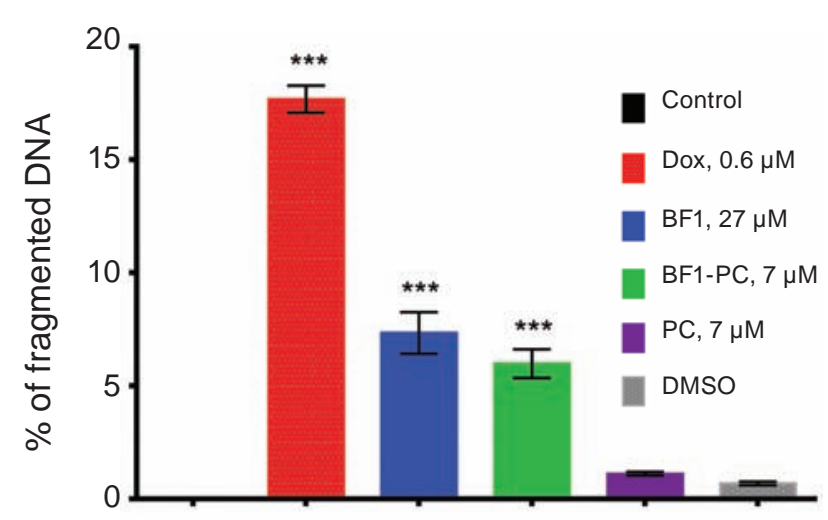

Fig. 5. The level of DNA fragmentation caused by the thiazole derivative $B F 1$, its complex with the $P C$ (BF1-PC), free PC, doxorubicin (Dox), and dimethyl sulfoxide (DMSO) in MDA-MB-231 cells. Barton's method with diphenylamine was used for quantitative identification of DNA fragmentation at $24 \mathrm{~h}$ after cell treatment. ${ }^{* * *} P<0.001$ (significant changes compared with cells treated with DMSO). Data are presented as mean $\pm S D(n=4)$. $P C$, polymeric carrier poly(PEGMA-co-DMM) 
and OTM = 6.7 (Figs. 6, C, 7). The BF1-PC complex $(7 \mu \mathrm{M})$ induced significant DNA damage with tail DNA $=15.5 \%$ and OTM = 11.9 (Figs. 6, $D, 7$ ). Dox $(0.6 \mu \mathrm{M})$ induced similar DNA damage with tail DNA $=14 \%$ and OTM $=5$ (Figs. 6, B, 7). The PC $(7 \mu \mathrm{M})$ and DMSO $(270 \mu \mathrm{g} / \mathrm{ml})$ induced little DNA damage, with tail DNA $=5.1 \%$ and OTM $=1.7$ for the PC (Figs. 6, E, 7) and tail DNA $=7.4 \%$ and $\mathrm{OTM}=1.6$ for DMSO (Figs. 6, F, 7). Some DNA damage (tail DNA $=8.7 \%$, OTM = 1.9) was detected in untreated cells (Figs. 6, A, 7). Thus, the thiazolebased derivative BF1 and its complex with the PC (BF1-PC) induced DNA single-strand breaks in the MDA-MB-231 cells.
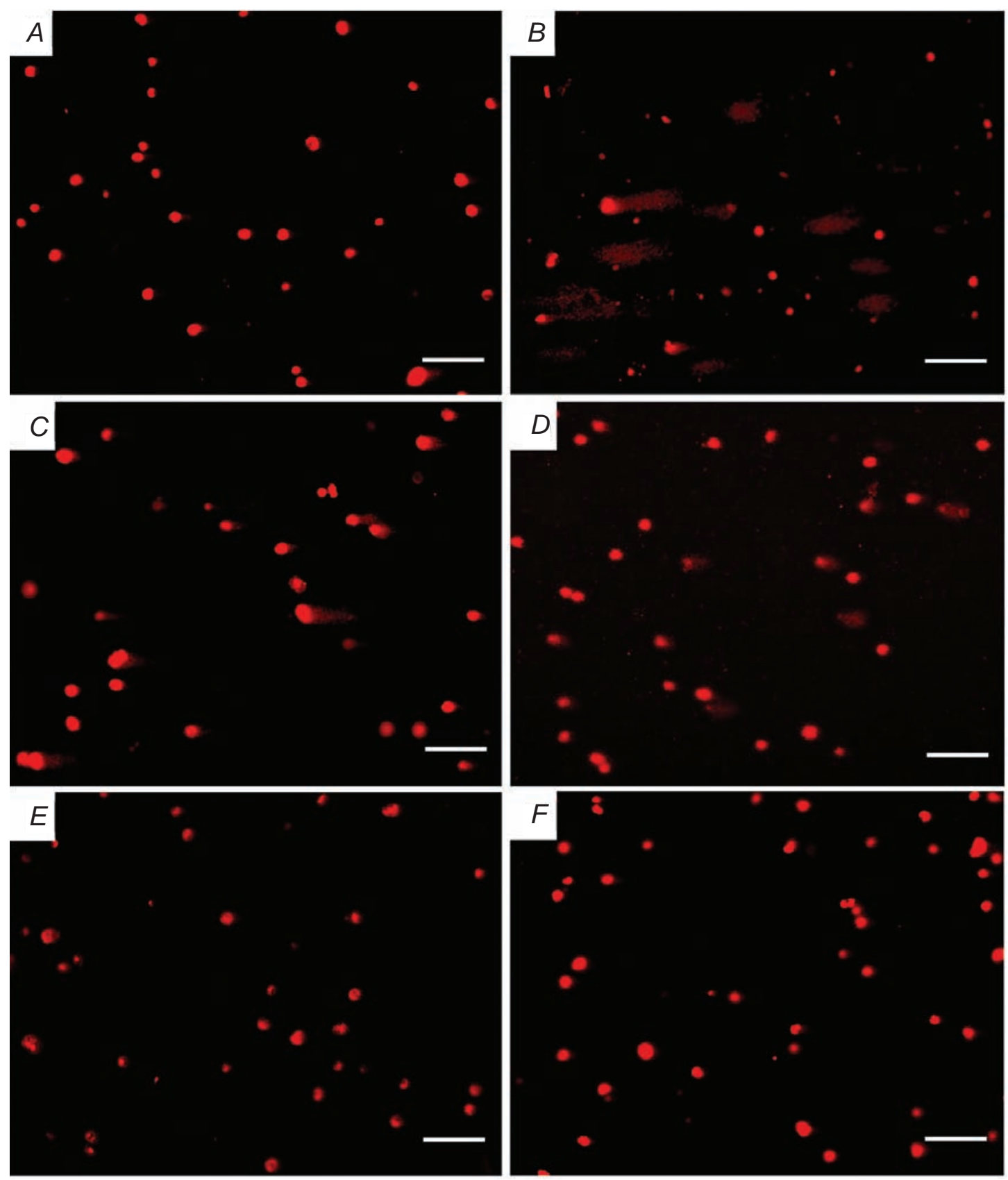

Fig. 6. The DNA damage effect of the studied compounds on MDA-MB-231 cells at 24 h after treatment: (A) control, (B) doxorubicin (Dox, $0.6 \mu \mathrm{M})$, (C) thiazole derivative BF1 (27 $\mu \mathrm{M})$; (D) complex of BF1 with the PC (BF1-PC, $7 \mu M) ;(E)$ free PC (7 $\mu M) ;(F)$ dimethyl sulfoxide (DMSO, $270 \mu \mathrm{g} / \mathrm{ml}$ corresponding to the solvent concentration of BF1 at $27 \mu \mathrm{M})$. The pictures of DNA comets under alkaline conditions are presented. Scale bars equal $50 \mu \mathrm{m}$. PC, polymeric carrier poly(PEGMA-co-DMM) 

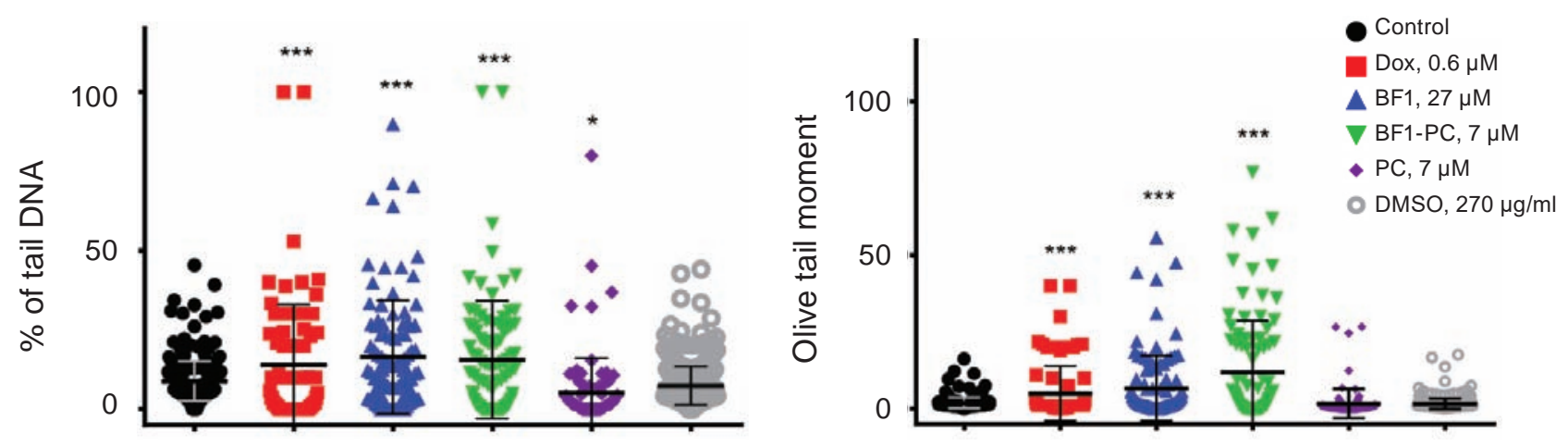

Fig. 7. The quantitative data of DNA damage in MDA-MB-231 cells after $24 \mathrm{~h}$ treatment with doxorubicin (Dox, $0.6 \mu M)$, thiazole derivative BF1 (27 $\mu M)$, complex of BF1 with the PC (BF1-PC, $7 \mu M)$, free PC (7 $\mu M)$, and dimethyl sulfoxide (DMSO, $270 \mu \mathrm{g} / \mathrm{ml}$ corresponding to the solvent concentration of BF1 at $27 \mu \mathrm{M}$ ). ${ }^{*} P<0.05, *^{* *} P<0.001$ (significant changes compared with control (untreated) cells). Data are presented as mean $\pm S D(n=4)$. PC, polymeric carrier poly (PEGMA-co-DMM)

Morphological study. The morphological study of MDA-MB-231 cells treated with BF1, BF1-PC complex, free PC, DMSO, and Dox was performed using cells stained with Hoechst 33342 and propidium iodide. BF1 (27 $\mu \mathrm{M})$ and the BF1PC complex $(7 \mu \mathrm{M})$ modified the shape of MDAMB-231 cells and changed the nucleus morphology (chromatin condensation, nuclear fragmentation, micronuclei), and caused membrane blebbing (Fig. 8, $E-H)$ compared with non-treated (control) cells (Fig. 8, A, B). Dox $(0.6 \mu \mathrm{M})$ caused condensation of chromatin and/or fragmentation of the nucleus, micronuclei formation, and membrane blebbing (Fig. 8, $C, D)$. Free PC $(7 \mu \mathrm{M})$ and DMSO $(270 \mu \mathrm{g} / \mathrm{mL})$ did not cause significant morphological changes (Fig. 8, $I-L)$. Thus, BF1 and the BF1-PC complex induced nuclear fragmentation, chromatin condensation, micronuclei formation and plasma membrane blebbing in treated MDA-MB-231cells.

\section{Discussion}

The thiazole-based compounds were created for targeting pathological cells, including tumor cells [5-12]. However, these compounds are often not easy to use because they are not soluble in water and the mechanisms of their action are not known. With the application of polymeric carriers, several problems of anticancer chemotherapy could be more successfully managed: 1) non-addressed action of anticancer medicines; 2) adverse effects; 3) multidrug resistance in tumor cells; 4) poor water solubility of many anticancer drugs [14-19].

In the present study, we demonstrated that the BF1-PC complex BF1 with the PC poly(PEGMA-co-
DMM)) possessed higher growth inhibition activity towards human breast adenocarcinoma cells of the MDA-MB-231 and MCF-7 lines. The cytotoxic action of the BF1-PC complex was approximately four times higher compared to the action of free BF1 towards MDA-MB-231 cells and approximately 1.6 times higher towards MCF-7 cells. It should be emphasized that the cytotoxic effect of the BF1-PC complex toward MDA-MB-231 cells (which are more malignant) was more pronounced compared to the effect of this complex toward MCF-7 cells. The PC did not demonstrate toxicity towards MDA-MB-231 or MCF-7 cells. In addition, the complex of BF1 with the PC poly(PEGMA-co-DMM) has shown higher activity in growth inhibition of human hepatocarcinoma HepG2 cells, human promyelocytic leukemia HL-60 cells and rat glioma C6 cells, compared to the activity of free BF1 [22].

Different mechanisms have been proposed for the antitumor action of the thiazole-based derivatives. It was reported that they acted as apoptosis inducers [6, 21, 25, 29], affected inosine monophosphate dehydrogenase (IMPDH) [29], induced reactive oxygen species (ROS) production [30], inhibited lipid peroxidation and caused DNA damage [5]. In the present study, we investigated the effect of thiazole derivative $\mathrm{BF} 1$ and its complexes with poly(PEGMA-co-DMM) on the stability of DNA in human breast adenocarcinoma MDA-MB-231 cells. It was found that these cells were more sensitive to the growth-inhibiting action of the BF1-PC complex compared with MCF-7 cells. The difference in response by two lines of human breast cancer cells MDA-MB-231 and MCF-7 - to the cytotoxic action 

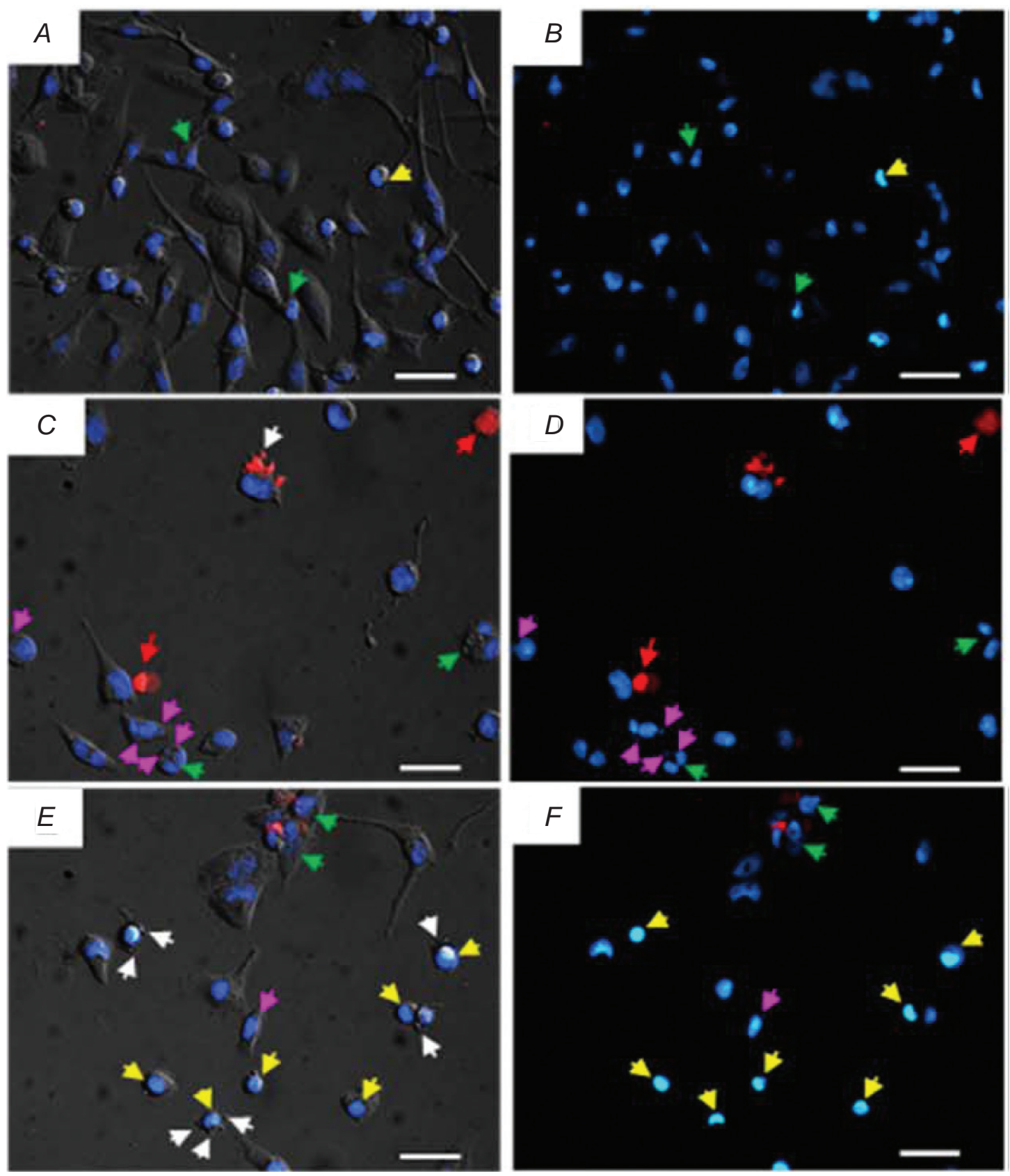

Fig. 8. Images of MDA-MB-231 cells treated for $24 \mathrm{~h}$ with the studied compounds: (A, B) control; (C, D) doxorubicin (Dox, $0.6 \mu \mathrm{M}) ;(\boldsymbol{E}, \boldsymbol{F})$ thiazole derivative BF1 $(27 \mu \mathrm{M})$. Left images - differential interference contrast (DIC) images of treated cells stained with Hoechst-33342 (blue color) and propidium iodide (red color). Right images - fluorescent images of treated and stained cells. Yellow arrows indicate chromatin condensation in cells, green arrows - chromatin fragmentation, pink arrows - micronucleus, white arrows - blebbing of plasma membrane. Scale bars equal $20 \mu \mathrm{m}$. PC, polymeric carrier poly(PEGMA-co-DMM)

of the BF1 and its complex with poly(PEGMA-coDMM) could be explained by various profiles of the regulatory proteins in cells of these two lines. The MCF-7 cells do not express the pro-apoptotic enzyme caspase 3 [31], while the MDA-MB-231 cells have this protein [32]. The complexation of BF1 with the PC enhanced its cytotoxic action towards more metastatic breast cancer cells (MDA-MB-231 line). MDA-MB-231 cells are the triple-negative breast cancer (TNBC) subtype. This is the estrogen- and progesterone-negative cell line that does not demonstrate an overexpression of human epidermal growth 

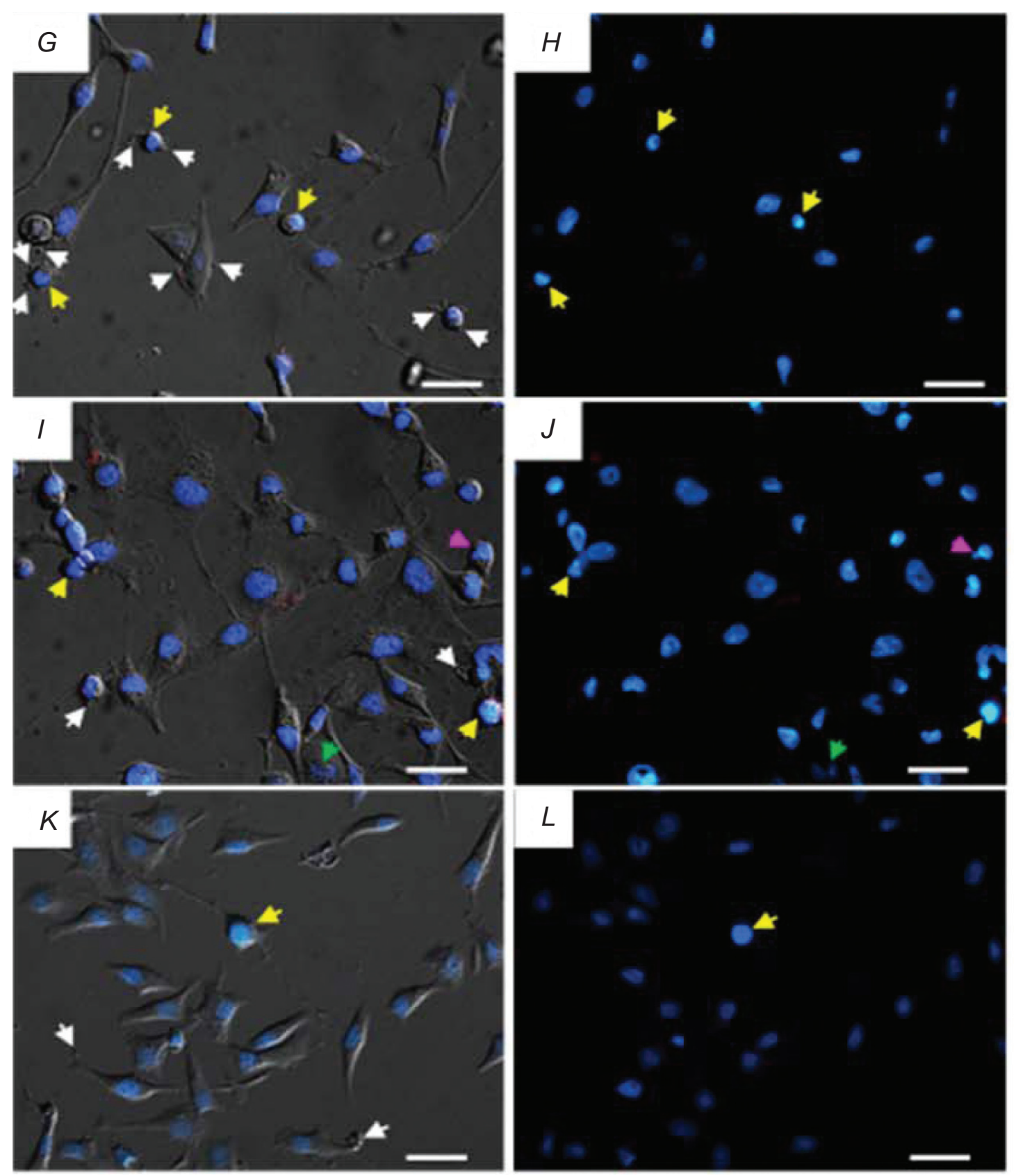

Fig. 8. Images of MDA-MB-231 cells treated for $24 \mathrm{~h}$ with the studied compounds: $(\boldsymbol{G}, \boldsymbol{H})$ complex of BF1 with the PC (BF1-PC, $7 \mu M) ;(I, J)$ free PC (7 $\mu M)$; (K, L) dimethyl sulfoxide (DMSO, $270 \mu \mathrm{g} / \mathrm{ml}$ corresponding to the solvent concentration of BFI at $27 \mu \mathrm{M})$. Left images - differential interference contrast (DIC) images of treated cells stained with Hoechst-33342 (blue color) and propidium iodide (red color). Right images fluorescent images of treated and stained cells. Yellow arrows indicate chromatin condensation in cells, green arrows - chromatin fragmentation, pink arrows - micronucleus, white arrows - blebbing of plasma membrane. Scale bars equal $20 \mu \mathrm{m}$. PC, polymeric carrier poly(PEGMA-co-DMM)

factor receptor-2 (HER2) [4]. The MDA-MB-231 cell line belongs to highly metastatic breast cancer cells [33] and it is a promising object for studying antineoplastic agents and systems for improvement of their antitumor action.
Several anticancer drugs that are currently used in chemotherapy were shown to interact with DNA either via covalent or non-covalent mechanisms. DNA interacting agents can change DNA conformation, interrupt DNA-protein interaction, or in- 
duce DNA strand breaks [34]. Unfortunately, some of them demonstrated high toxicity for both tumor and normal cells [10,34]. Based on the results of the electrophoretic retardation of plasmid DNA and methyl green replacement assay, we concluded that BF1 and the BF1-PC complex could not bind DNA or intercalate into its molecule.

It was reported that bleomycin, a bisthiazolyl derivative, acted as an antitumor agent due to its DNA binding [10]. However, the platinum(II)and platinum(IV)-pyrophosphato-complexes (e.g. trans-1,2-cyclohexanediamine and pyrodach-2) that exhibit cytotoxicity towards ovarian cell lines do not bind to DNA molecules [35]. The NB-506, isolated from Streptoverticillium species culture supernatants, did not intercalate into DNA and possessed high toxicity towards a panel of tumor cells [36]. Grozav et al. [37] reported about the toxicity of 2-(2-benzyliden-hydrazinyl)-4-methylthiazole derivative (97a) towards MDA-MB-231 $\left(\mathrm{IC}_{50}=3.92 \mu \mathrm{g} /\right.$ $\mathrm{ml})$ and $\mathrm{HeLa}\left(\mathrm{IC}_{50}=11.4 \mu \mathrm{g} / \mathrm{ml}\right)$ cell lines. The toxicity of this compound was comparable to that found for the commercial chemotherapeutic agents cisplatin and oxaliplatin. The $\mathrm{IC}_{50}$ for cisplatin was $17.28 \mu \mathrm{g} / \mathrm{ml}$ for MDA-MB-231 cells and $26.12 \mu \mathrm{g} /$ $\mathrm{ml}$ - for HeLa cells, while the $\mathrm{IC}_{50}$ for oxaliplatin was $14.09 \mu \mathrm{g} / \mathrm{ml}$ for MDA-MB-231 cells and $23.17 \mu \mathrm{g} /$ $\mathrm{ml}$ for HeLa cells. The results of gel electrophoresis of DNA suggest that the antiproliferative activity of the 97a derivative towards MDA-MB-231 and HeLa cells was independent of DNA intercalation [35].

Thus, several anticancer agents do not bind or intercalate into DNA molecules, however, such intercalation may be an alternative mechanism of the anticancer activity of some agents.

DNA fragmentation is another indicator of the catabolic changes related to the apoptotic pathway [38]. DNA comet analysis under the alkaline conditions is widely used for the investigation of DNA damage in cells under the action of different agents and drugs [28]. We have shown that the thiazolebased derivative BF1 and the BF1-PC complex induced significant DNA damage in the MDA-MB-231 cells, however, only minor DNA damage was detected in the MDA-MB-231 cells treated with free PC or the DMSO solvent. Cytomorphological investigation of the treated MDA-MB-231 cells showed that $\mathrm{BF} 1$ and the BF1-PC complex induced nuclear fragmentation, chromatin condensation, micronuclei formation and plasma membrane blebbing. The free PC and DMSO did not cause these significant morpho- logical changes. These findings correlate with previously reported data that 2-amino-5-benzylthiazole derivatives (2,8-dimethyl-7-(3-trifluoromethyl-benzyl)pyrazolo[4,3-e]thiazolo[3,2-a]pyrimidin-4(2H)one; and 7-benzyl-8-methyl-2-propylpyrazolo[4,3-e] thiazolo[3,2-a]pyrimidin-4(2H)-one) induced DNA single-strand breaks and DNA fragmentation in human leukemia cells without significant DNA binding and DNA intercalation [25]. The furan-thiazole hybrid (compound 3d) exhibited its anticancer activity via DNA binding and DNA damage [12].

Taking into account the results of our study, one cannot exclude that in addition to the DNA damaging mechanisms of the cytotoxic action of the thiazole-based derivative BF1 and its complex with the PC towards human breast adenocarcinoma cells (MDA-MB-231 line), other mechanisms of action of these compounds should also be considered. We plan to undertake such corresponding investigations for our future work, particularly on tumor-bearing laboratory animals.

Conclusion. Thiazole-based derivative BF1 demonstrates cytotoxic action towards human breast adenocarcinoma cells of the MDA-MB-231 and MCF-7 lines. The immobilization of BF1 on the PC poly(PEGMA-co-DMM) increased fourfold the cytotoxicity of the BF1 towards MDA-MB-231 cells and doubled its cytotoxicity towards MCF-7 cells, while free PC did not demonstrate significant cytotoxic action. The BF1 compound and BF1-PC complex did not intercalate into DNA or bind with its molecule. However, they induced morphological changes in the treated MDA-MB-231 cells, such as nuclear fragmentation, chromatin condensation, micronuclei formation and plasma membrane blebbing.

Conflict of interest. Authors have completed the Unified Conflicts of Interest form at http://ukrbiochemjournal.org/wp-content/uploads/2018/12/ coi_disclosure.pdf and declare no conflict of interest.

Funding. This research was supported by the Ministry of Education and Science of Ukraine grants (registration number 0119U002201 and 0118U000260), and partially by Cedars-Sinai Medical Center's International Research and Innovation in Medicine Program and the Association for Regional Cooperation in the Fields of Health, Science and Technology (RECOOP HST Association) and the participating Cedars-Sinai Medical Center RECOOP Research Centers (CRRCs). 


\section{ВПЛИВ НОВОГО ПОХІДНОГО ТІАЗОЛУ ТА ЙОГО КОМПЛЕКСУ З ПОЛІМЕРНИМ НОСІЕМ НА СТАБІЛЬНІСТЬ ДНК КЛІТИН РАКУ МОЛОЧНОї ЗАЛОЗИ ЛЮДИНИ}

\author{
Н. С. Фінюк ${ }^{1,2}$, О. Ю. Ключівська \\ I. I. Івасечко , H. С. Мітіна \\ Ю. В. Остап'юк ${ }^{2}$ М. Д. Обушак', \\ A. М. Бабський ${ }^{2}$, P. С. Стойка ${ }^{1,2 \bowtie}$ \\ ${ }^{1}$ Інститут біології клітини НАН \\ України, Львів, Україна; \\ ${ }^{2}$ Львівський національний університет \\ імені Івана Франка, Львів, Україна; \\ ${ }^{3}$ Національний університет «Львівська \\ політехніка», Львів, Україна; \\ ๑e-mail: stoika.rostyslav@gmail.com
}

Похідні тіазолу характеризуються широким спектром біологічної дії, зокрема діють як протипухлинні агенти. Для підвищення ефективності біологічної дії ліків, покращення їхньої біосумісності та розчинності у воді широко використовують полімерні носії. Раніше нами було показано, що BF1 (N-(5-бензил-1,3-тіазол2-іл)-3,5-диметил-1-бензофуран-2-карбоксамід) виявляе токсичну дію щодо пухлинних клітин різного тканинного походження. Метою роботи було дослідити in vitro дію сполуки BF1 та iï комплексу 3 полімерним носієм (РC) полі(PEGMA-co-DMM) (комплекс BF1-PC) на клітини ліній MDA-MD-231 та MCF-7 аденокарциноми молочної залози людини. ДНК кометаналіз, метод із використанням дифеніламіну, електрофорез ДНК в агарозному гелі, аналіз інтеркаляції ДНК із використанням метилового зеленого та флуоресцентна мікроскопія були застосовані для вивчення впливу BF1 на стабільність ДНК у клітинах аденокарциноми молочної залози людини. Показник цитотоксичної дії $\mathrm{IC}_{50}$ сполуки $\mathrm{BF} 1$ для клітин лінії MDA-MB-231 становив 26,5 $\pm 2,9$ мкМ, а для комплексу BF1-PC $-6,9 \pm 0,4$ мкM, РС мав низьку токсичність $\left(\mathrm{IC}_{50}>50\right.$ мкM). Комплекс BF1-PC проявляв більшу токсичну дію щодо клітин лінії MCF-7, ніж вільний $\mathrm{BF} 1$, так $\mathrm{IC}_{50}$ становив відповідно 9,6 $\pm 0,8$ та 15,8 \pm 0,9 мкМ. BF1 i BF1-PC збільшували кількість пошкоджених клітин, спричинювали блебінг плазматичної мембрани, конденсацію хроматину i/або фрагментацію ядра клітин лінії MDA-MB-231.
BF1 і BF1-PC індукували однониткові розриви і фрагментацію ДНК в клітинах лінії MDAMB-231. Досліджувані сполуки не взаємодіяли з плазмідною ДНК і не інтеркалювали в їі молекулу.

К лючнв і слов а: похідне тіазолу, полімерний носій, цитотоксична дія, клітини раку молочної залози, пошкодження ДНК, комет-аналіз ДНК, інтеркаляція ДНК.

\section{References}

1. Rashid M, Shrivastava N, Husain A. Synthesis and SAR strategy of thiazolidinedione: a novel approach for cancer treatment. J Chil Chem Soc. 2020; 65(2): 4817-4832.

2. Mirza AZ, Althagafi II, Shamshad H. Role of PPAR receptor in different diseases and their ligands: Physiological importance and clinical implications. Eur J Med Chem. 2019; 166: 502513.

3. Siegel RL, Miller KD, Jemal A. Cancer statistics, 2019. CA Cancer J Clin. 2019; 69(1): 7-34.

4. Mohammed F, Rashid-Doubell F, Taha S, Cassidy S, Fredericks S. Effects of curcumin complexes on MDA-MB-231 breast cancer cell proliferation. Int J Oncol. 2020; 57(2): 445-455.

5. ELAblack FZ, Elgazzar UB, Hashem A. Antitumor activity of novel azole compound against Ehrlich ascites carcinoma in swiss albino mice. Insi Chem Biochem. 2020; 1(2): 2020.

6. Leoni A, Locatelli A, Morigi R, Rambaldi M. Novel thiazole derivatives: a patent review (2008 - 2012. Part 2). Expert Opin Ther Pat. 2014; 24(7): 759-777.

7. Ayati A, Emami S, Moghimi S, Foroumadi A. Thiazole in the targeted anticancer drug discovery. Future Med Chem. 2019;11(15):19291952.

8. Jain S, Pattnaik S, Pathak K, Kumar S, Pathak D, Jain S, Vaidya A. Anticancer potential of thiazole derivatives: A retrospective review. Mini Rev Med Chem. 2018; 18(8): 640-655.

9. de Siqueira LRP, de Moraes Gomes PAT, de Lima Ferreira LP, de Melo Rêgo MJB, Leite ACL. Multi-target compounds acting in cancer progression: Focus on thiosemicarbazone, thiazole and thiazolidinone analogues. Eur $J$ Med Chem. 2019; 170: 237-260.

10. Turan-Zitouni G, Altıntop MD, Özdemir A, Kaplancıklı ZA, Çiftçi GA, Temel HE. Synthesis 
and evaluation of bis-thiazole derivatives as new anticancer agents. Eur J Med Chem. 2016; 107: 288-294.

11. Kantarjian H, Jabbour E, Grimley J, Kirkpatrick P. Dasatinib. Nat Rev Drug Discov. 2006; 5(9): 717718.

12. El-Wakil MH, El-Yazbi AF, Ashour HMA, Khalil MA, Ismail KA, Labouta IM. Discovery of a novel DNA binding agent via design and synthesis of new thiazole hybrids and fused 1,2,4-triazines as potential antitumor agents: Computational, spectrometric and in silico studies. Bioorg Chem. 2019; 90: 103089.

13. Wagner AM, Gran MP, Peppas NA. Designing the new generation of intelligent biocompatible carriers for protein and peptide delivery. Acta Pharm Sin B. 2018; 8(2): 147-164.

14. Mitchell MJ, Billingsley MM, Haley RM, Wechsler ME, Peppas NA, Langer R. Engineering precision nanoparticles for drug delivery. Nat Rev Drug Discov. 2021; 20(2): 101124.

15. Pradhan D, Biswasroy P, Goyal A, Ghosh G, Rath G. Recent advancement in nanotechnologybased drug delivery system against viral infections. AAPS PharmSciTech. 2021; 22(1): 47.

16. Culver HR, Clegg JR, Peppas NA. Analyteresponsive hydrogels: intelligent materials for biosensing and drug delivery. Acc Chem Res. 2017; 50(2): 170-178.

17. Cheng Q, Wei T, Farbiak L, Johnson LT, Dilliard SA, Siegwart DJ. Selective organ targeting (SORT) nanoparticles for tissue-specific mRNA delivery and CRISPR-Cas gene editing. Nat Nanotechnol. 2020;15(4):313-320.

18. Rideau E, Dimova R, Schwille P, Wurm FR, Landfester K. Liposomes and polymersomes: a comparative review towards cell mimicking. Chem Soc Rev. 2018; 47(23): 8572-8610.

19. Anselmo AC, Mitragotri S. Nanoparticles in the clinic: An update. Bioeng Transl Med. 2019; 4(3): e10143.

20. Finiuk NS, Hreniuh VP, Ostapiuk YuV, Matiychuk VS, Frolov DA, Obushak M D, Stoika RS, Babsky AM. Antineoplastic activity of novel thiazole derivatives. Biopolym Cell. 2017; 33(2): 135-146.

21. Finiuk N, Klyuchivska O, Ivasechko I, Hreniukh V, Ostapiuk Yu, Shalai Ya, Panchuk R, Matiychuk V, Obushak M, Stoika R, Babsky A. Proapoptotic effects of novel thiazole derivative on human glioma cells. Anticancer Drugs. 2019; 30(1): 27-37.

22. Finiuk NS, Popovych MV, Shalai YaR, Mandzynets SM, Hreniuh VP, Ostapiuk YuV, Obushak MD, Mitina NE, Zaichenko OS, Stoika RS, Babsky AM. Antineoplastic activity in vitro of 2-amino-5-benzylthiasol derivative in the complex with nanoscale polymeric carriers. Cytol Genet. 2021; 55(1): 19-27.

23. Paiuk OL, Mitina NYe, Kinash NI, Yakymovych AB, Hevus OI, Zaichenko AS. Comb-like polyethylene glycol containing oligomeric surfactants with reactive terminal groups. Ukr Chem J. 2018; 84(10): 98-106. (In Ukrainian).

24. Mitina NYe, Riabtseva AO, Garamus VM, Lesyk RB, Volyanyuk KA, Izhyk OM, Zaichenko OS. Morphology of the micelles formed by a comb-like PEG-containing copolymer loaded with antitumor substances with different water solubilities. Ukr J Phys. 2020; 65(8): 670.

25. Finiuk NS, Ivasechko II, Klyuchivska OYu, Ostapiuk YuV, Hreniukh VP, Shalai YaR, Matiychuk VS, Obushak MD, Babsky AM, Stoika RS. Apoptosis induction in human leukemia cells by novel 2-amino-5benzylthiazole derivatives. Ukr Biochem $J$. 2019; 91(2): 29-39.

26. Filak LK, Mühlgassner G, Jakupec MA, Heffeter P, Berger W, Arion VB, Keppler BK. Organometallic indolo[3,2-c]quinolines versus indolo[3,2-d]benzazepines: synthesis, structural and spectroscopic characterization, and biological efficacy. J Biol Inorg Chem. 2010; 15(6): 903-918.

27. Arora S, Tandon S. DNA fragmentation and cell cycle arrest: a hallmark of apoptosis induced by Ruta graveolens in human colon cancer cells. Homeopathy. 2015; 104(1): 36-47.

28. Liao W, McNutt MA, Zhu WG. The comet assay: a sensitive method for detecting DNA damage in individual cells. Methods. 2009; 48(1): 46-53.

29. Matsuya Y, Kawaguchi T, Ishihara K, Ahmed K, Zhaov, Kondo T, Nemoto H. Synthesis of macrosphelides with a thiazole side chain: new antitumor candidates having apoptosis-inducing property. Org Lett. 2006; 8(20): 4609-4612.

30. Shalai YaR, Popovych MV, Kulachkovskyy OR, Hreniukh VP, Mandzynets SM, Finiuk NS, Babsky AM. Effect of novel 2-amino- 
5-benzylthiazole derivative on cellular ultrastructure and activity of antioxidant system in lymphoma cells. Stud Biol. 2019; 13(1): 51-60.

31. Bilyy RO, Shkandina T, Tomin A, Muñoz LE, Franz S, Antonyuk V, Kit YY, Zirngibl M, Fürnrohr BG, Janko C, Lauber K, Schiller M, Schett G, Stoika RS, Herrmann M. Macrophages discriminate glycosylation patterns of apoptotic cell-derived microparticles. J Biol Chem. 2012; 287(1): 496-503.

32. Yang S, Zhou Q, Yang X. Caspase-3 status is a determinant of the differential responses to genistein between MDA-MB-231 and MCF-7 breast cancer cells. Biochim Biophys Acta. 2007; 1773(6): 903-911.

33. Tu YF, Kaipparettu BA, Ma Y, Wong LJ. Mitochondria of highly metastatic breast cancer cell line MDA-MB-231 exhibits increased autophagic properties. Biochim Biophys Acta. 2011; 1807(9): 1125-1132.

34. Sirajuddin M, Ali S, Badshah A. Drug-DNA interactions and their study by UV-Visible, fluorescence spectroscopies and cyclic voltametry. J Photochem Photobiol B. 2013; 124: 1-19.
35. Bose RN, Maurmann L, Mishur RJ, Yasui L, Gupta S, Grayburn WS, Hofstetter H, Salley T. Non-DNA-binding platinum anticancer agents: Cytotoxic activities of platinum-phosphato complexes towards human ovarian cancer cells. Proc Natl Acad Sci USA. 2008; 105(47): 1831418319.

36. Bailly C, Dassonneville L, Colson P, Houssier C, Fukasawa K, Nishimura S, Yoshinari T. Intercalation into DNA is not required for inhibition of topoisomerase I by indolocarbazole antitumor agents. Cancer Res. 1999; 59(12): 2853-2860.

37. Grozav A, Găină LI, Pileczki V, Crisan O, SilaghiDumitrescu L, Therrien B, Zaharia V, BerindanNeagoe I. The synthesis and antiproliferative activities of new arylidene-hydrazinyl-thiazole derivatives. Int J Mol Sci. 2014; 15(12): 2205922072.

38. Basnakian AG, Apostolov EO, Yin X, Abiri SO, Stewart AG, Singh AB, Shah SV. Endonuclease $\mathrm{G}$ promotes cell death of non-invasive human breast cancer cells. Exp Cell Res. 2006; 312(20): 4139-4149. 